\title{
Research on the Construction of E-commerce Platform for Poverty Alleviation Products Based on Internet
}

\author{
Xinjiang Qiao ${ }^{1}$, Weiping $\mathrm{Ai}^{2 *}$, Xuan $\mathrm{Chen}^{3}$, Ximing Feng ${ }^{4}$ \\ 1234 Jiangxi University of Traditional Chinese Medicine, Nanchang, Jiangxi,330004 \\ Subject: Research on the Reform of Ideological and Political Education for College Students in Jiangxi Province in 2020
}

\begin{abstract}
With the development of the current Internet, e-commerce has also shown a vigorous vitality. The development of China's new poverty alleviation model is also closely related to the Internet ecommerce platform. The construction of e-commerce platform has gradually become an important path to get rid of poverty in rural areas. Through a series of analysis, this paper summarizes some current situation of e-commerce development and some effects achieved by e-commerce platform in poverty alleviation, and summarizes the experience and poverty alleviation model of some domestic e-commerce platforms. Finally, the feasibility of the current agricultural products e-commerce poverty alleviation model is studied and discussed.
\end{abstract}

\section{Introduction}

In order to achieve the goal of all Chinese people on the road to prosperity, the country is carrying out a series of revitalization activities for the rejuvenation of rural economy. To achieve rural stability, farmers' income, agricultural development, the "three rural" goal. With the development of Internet economy in China, various payment platforms are gradually pouring out, which brings a series of convenience to people's life. In the development of China in the past ten years, e-commerce has been booming in China. Under this very good prospect, the combination of rural poverty alleviation and Internet e-commerce can effectively promote the development of rural economy and realize the income growth of poor farmers. Based on the above conditions, the national leaders of China pay more and more attention to the development of rural e-commerce out of poverty, and gradually regard the development of e-commerce as one of the important development projects in and think that e-commerce is an effective way to help the poor in rural areas. Therefore, the development advantage of rural e-commerce poverty alleviation is very promising. The study of rural ecommerce poverty alleviation methods has no great reference significance for relevant local poverty alleviation activities.

\section{Current Situation of E-commerce in China}

\subsection{Large number of Internet users}

According to the current statistics of Internet users in China, the number of Internet users in China is increasing from 2008 to 2018. By 2018, the scale of Internet users in China has exceeded 800 million, the specific development data as shown below.

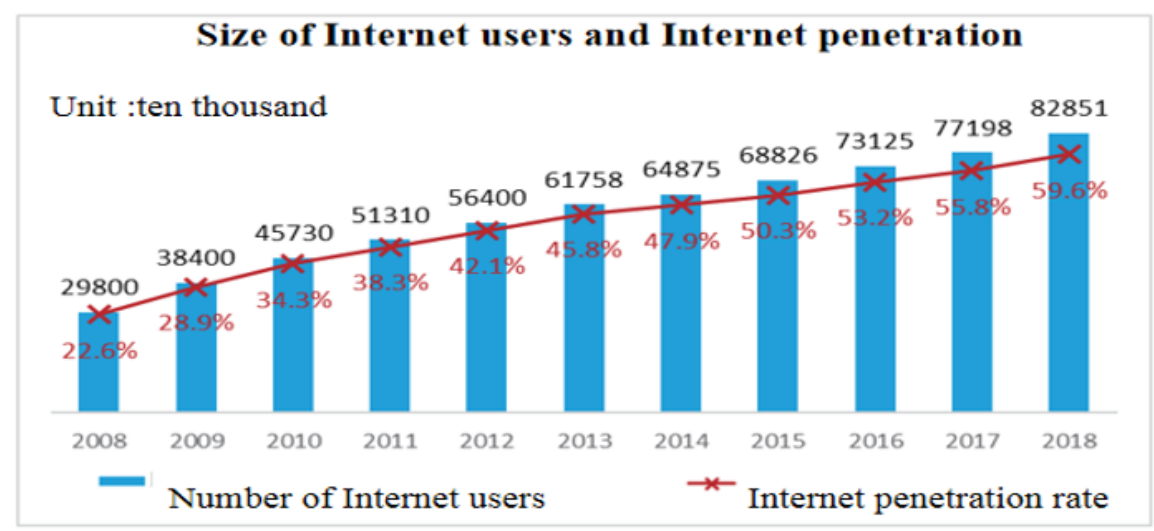

Fig. 1. Size of Internet users and Internet penetration

*Corresponding author's e-mail: 842663792@qq.com 
Although the scale of Internet users in China is very large, the current Internet penetration rate has not achieved the desired results. From these data levels, we can see that the current popularity of the Internet in China still has a very large development prospects[1].

Another level is that the current economic strength and comprehensive ability of China has been continuously improved. With the expansion of the number of Internet users, the current Internet network environment is gradually improved. According to the current communication bulletin, China has improved a number of mobile communication base stations. Besides these, with the advanced development of $5 \mathrm{G}$ technology in China, this will also provide a strong development power for the development of Internet in China.

\subsection{Current situation of e-commerce poverty alleviation}

With the improvement of Internet technology, the online economy has been booming, and many enterprises want to occupy a certain share from the online economy. At present, in the online economy, individuals can also join e-commerce development in a low-investment way. At present, the development of e-commerce platform has blossomed everywhere, occupies a certain position in people's hearts, and widely exists in the life of today's people.

Nowadays, the development of the Internet is gradually accelerating. In the continuous development of the Internet, also derived a series of mobile payment means, this means of payment because of its convenient and convenient use of the environment, has been loved by the majority of the people. In this payment environment, people also have a strong interest in online shopping, online shopping also pay more attention to the development of e-commerce industry. Online payment is characterized by greater flexibility than traditional offline payment and face-to-face payment. In the ecommerce model, the radiation surface of this poverty alleviation model is relatively large, the transmission distance is long, and the source of tourists is many. This shows that this new poverty alleviation model is more effective than some traditional offline poverty alleviation methods.

With the attention of the country to poverty alleviation and development, the major enterprises have launched some poverty alleviation platforms. For example, among some e-commerce giants in China, Alibaba, China Post and JingDong. More enterprises pay more and more attention to the development of poverty alleviation industry, and find a new way for the development of poverty alleviation industry. These platforms also recognize that the online pro-poor ecommerce model is much better than the traditional offline pro-poor model. Many online e-commerce companies have also set up special poverty alleviation projects for today's poverty alleviation and development, dedicated to changing poverty in remote areas. In addition to these, we also send professionals to create some special poverty alleviation brands, sign cooperation letters, and establish poverty alleviation cooperative relations[2].

\section{Major Problems Facing the Development of E-commerce in China}

\subsection{Lack of e-commerce in rural areas}

In 2015, our government has issued the corresponding ecommerce poverty alleviation documents. However, under the introduction of this document, China's ecommerce poverty alleviation platform has not been well developed. Although China's Internet technology has been booming, the development model of e-commerce industry is becoming more and more mature. However the rural poverty alleviation platform is still not developed. One of the biggest reasons is the lack of corresponding e-commerce talents in rural areas, one of which is that the awareness of e-commerce development in rural areas is still relatively weak, people do not know much about this new model. In the development of rural poverty alleviation e-commerce, now this development model is still in its infancy, people dare not rush to make some investment, many farmers have not really come into contact with the e-commerce industry. The second reason is because of related skills. The cultural quality of the rural population is relatively low, most of the population is graduated from junior high school and some vocational schools. For some of the current consumer markets and some new means of consumption know less. In addition, the development of e-commerce platform is also relatively fast, to learn more skills, this is a very big challenge for them. Under this series of development, the development of rural poverty alleviation model is difficult to carry out.

\subsection{Product quality good and bad}

In the consumption experience of poverty alleviation in rural areas, consumers also give the uneven quality of some products in rural areas. This is also an important issue restricting the development of agricultural ecommerce. For these rural products, the natural environment in poor areas is mostly barren, and most farmers rely on heaven to eat. In these poor land, it is difficult to grow relatively high-quality crops. Then most farmers use chemical fertilizer to accumulate to improve the quality of agricultural products, but these unreasonable planting methods will also lead to the lack of quality of some agricultural products. Without the professional guidance of relevant experts, rural products are mostly low production and a series of quality problems. These reasons lead to some conditions in the quality of agricultural products. As a result, the income cost of rural areas is less than the cost of planting, so that some of the income of farmers in poor areas can not be guaranteed[3]. 


\subsection{Inadequate e-commerce infrastructure}

In the rural e-commerce poverty alleviation development model, or lack of a series of public resources. In some traditional sources of income, the majority of farmers' income is relatively single, the level of development is also relatively low, most of them rely on planting agricultural products to obtain meagre income. In the case of these income, the rural population does not have the corresponding funds to support the development of ecommerce. Therefore, in the corresponding poor areas. The development of public infrastructure is weak, the terrain is relatively closed, and the traffic is still in the less developed stage. In these cases, most of the ecommerce infrastructure can not be shipped to the corresponding area. This series of development leads to the rural e-commerce platform is still in its infancy. Therefore, under this condition, the development of ecommerce platform should constantly expand some industrial chains of rural products, increase the added value of agricultural products, and develop some new industries to bring new benefits to farmers. We should try our best to develop some agricultural e-commerce models, do a good job of basic services, and try our best to improve development facilities[4].

\subsection{Weak brand construction consciousness}

In the development of e-commerce platform, people's awareness of brand building is relatively weak. Whether it's a good product or a bad product. Local people have no idea to build brand awareness. The quality of some products is also uneven, lack of some professional quality control and supervision. Consumers in the purchase, also lack some quality awareness. Many rural products, although high-quality products, but also do not rule out some bad businesses for the poverty-alleviation products for some intellectual property theft. This makes consumers unable to identify the difference between the two, which will have a certain impact on the reputation of poverty alleviation agricultural products. It will cause a series of development problems for the future development of agricultural products.

\section{Advantages and Significance of E- commerce Platform Construction for Poverty Alleviation Products}

\subsection{Advantages of e-commerce platform construction for poverty alleviation products}

The development of rural e-commerce has strong plasticity. In Chinese poverty alleviation road, China has never ignored the information construction for the remote countryside. Long ago, China began to provide a large number of development resources for rural information construction. Now with the development of poverty alleviation mode in China, some information construction in rural areas is gradually improved, and the popularization rate of the Internet is getting higher and higher. These developments have provided good infrastructure for the development of rural e-commerce. E-commerce of agricultural products is a necessary way to help the poor and develop, because the content of ecommerce development in China is becoming more and more perfect, and rural e-commerce is more like a new development opportunity. This development opportunity is also one of the key points of Chinese current and future development, which is a major measure to promote our population out of poverty. And the current development conditions in China are also conducive to the construction of pro-poor product e-commerce platform, the specific advantages are as follows[5].

Rural infrastructure is relatively perfect, transportation is also more developed, the distance between urban and rural development is shrinking.

For the major issue of poverty alleviation, the relevant government has also issued a series of measures. The government has also given a lot of preferential policies, providing some talents training, logistics cost subsidies, tax burden support, and encouraging some young college students to return home to start a business. The support of these conditions has provided a good development environment for the development of rural e-commerce platform.

The development of poverty alleviation e-commerce work can promote the effective use of local labor force. Rural areas because of some traditional economic income channels. There is a large surplus of labor without a platform to release. The current e-commerce poverty alleviation platform can effectively utilize the local surplus labor force, improve the local economic productivity and promote the increase of farmers' income.

The trading activities of agricultural products ecommerce platform can reduce service cost and logistics cost. In the current Internet information gradually improved. Small producers can sell their products well at low cost, on the basis of which they can reduce the transaction costs in rural areas and make farmers more profitable.

In addition to these, there are vast rural productivity has not been adequately developed. With the gradual development of e-commerce platform, the surplus productive forces in rural areas can also be well developed[6].

\subsection{Significance of E-commerce Platform for Poverty Alleviation Products}

In the continuous development of e-commerce platform in China, e-commerce platform has become a new development model of poverty alleviation, which has brought us great advantages. In a series of poverty alleviation and development, e-commerce platform gives rural areas good development opportunities and development environment. The development of poverty alleviation e-commerce is also conducive to the government to achieve the goal of poverty alleviation; it is conducive to raising the income of people in poor areas; this has made a great contribution to winning the battle against poverty. In the development of pro-poor e- 
commerce, not only the poor in poverty-stricken areas, but also the vast number of consumers. The onlineization of agricultural products gives offline consumers a larger consumption platform and more meets some shopping needs of corresponding consumers. Overall. The development of poverty alleviation e-commerce platform not only promotes the development of poverty alleviation in China, but also promotes the development of corresponding industries in China to a certain extent. Under the display of this kind of development achievement, the development of poverty alleviation ecommerce is a good development model. In the future, we should constantly enrich this model and try our best to make poverty alleviation e-commerce bigger and better. To meet the consumption of more people, in line with the development of the times, a new path of rural poverty alleviation and development.

\section{The Way of E-commerce Platform Construction of Pro-poor Products from the Perspective of Internet}

\subsection{Building partnerships with e-commerce platforms}

In the development of rural e-commerce poverty alleviation, we should continue to strengthen the establishment of a certain cooperative relationship with major e-commerce platforms. Through some cooperation with the corresponding e-commerce platform, we can create a new mode of e-commerce poverty alleviation with corresponding regional characteristics, thus promoting the common development of rural areas and enterprises. At present, JingDong Group and Alibaba Group have made a great attempt to the development of poverty alleviation industry. JingDong industry helps the development of rural industry in China through the construction of local specialty brands. In the Alibaba poverty alleviation model, the establishment of a number of Taobao villages. So far, Taobao Village has made a very important contribution to the construction of poverty alleviation industrial model, and the effect is also very remarkable. In the continuous development of Internet e-commerce platform, the number of Taobao villages is also increasing, and the turnover is constantly reaching a record high. With the continuous development of Taobao Village, the intervention of ecommerce platform has improved the public infrastructure of rural e-commerce platform, and brought new vitality and vitality to the development of rural poverty alleviation[7].

The cooperation between the rural industry poverty alleviation model and the corresponding e-commerce platform can not only improve the ability of rural products to connect with the consumer market, but also establish a brand consciousness and group consciousness through the corresponding platform. With the continuous development of Internet e-commerce platform, it has gradually improved some development paths of rural poverty alleviation and development. This development not only promotes the development of rural economy, but also promotes the development of corresponding industries. It brings a series of employment opportunities to the local people and increases the income of farmers. In addition to these, the rural development environment also makes a large number of young people gradually focus on the development of rural areas, most of the graduates are also actively involved in rural areas to start a business.

Through the development of rural products and related enterprises to cooperate with a series of resource integration. With the help of these enterprises, rural areas can actively improve the quality and output of agricultural products, create high-quality industrial brands, and make most people go to the road of getting rid of poverty and becoming rich.

\subsection{Introduce relevant talents and establish cooperative relationship with research institutes colleges and universities}

Under the poverty alleviation mode of rural industry, we should also establish the cooperative relationship with colleges and universities and corresponding research institutes through the corresponding departments. Through these cooperation, we can seek some talent groups to help and support the development of rural industries. In the case of these developments, teachers and students of research institutes and colleges and universities can carry out a series of knowledge training and skills training for farmers corresponding professional knowledge in rural areas. To help local farmers understand the current development model of ecommerce in China and the development situation and some future development prospects. To provide a new development strategy and development policy for rural development. Through a series of examples to prove some advantages of e-commerce development, promote the development of local rural e-commerce industry. In addition to knowledge training for some e-commerce industries in rural areas, we can also set up local service stations, such as research bases and service centers. Through these services to improve the development competitiveness of local industries and market adaptability. In order to develop in the long run, we also have to build a team, such as propaganda team, operation team and brand building team, which can not only attract young labor force to return home to start a business, but also help e-commerce to help the poor. Reduce the number of local left-behind children and left-behind elderly, and promote the long-term development of rural poverty alleviation.

\subsection{Integration of rural poverty alleviation with tourism development}

With the continuous development of the Internet, agricultural products and e-commerce are more and more closely linked. Under this development mode, a new industrial model has been derived, that is, under the influence of the Internet and e-commerce platform, the 
development of tourism has been added. This poverty alleviation model promotes the joint development of primary industry, secondary industry and tertiary industry. The emergence of this poverty alleviation model provides more possibilities for the development of poverty alleviation industry in China. E-commerce platform can not only promote the development of local economy, but also promote local traditional culture and some characteristic industries to a certain extent, and promote the development of local tourism. In the development of tourism, the major platforms can form local unique tourist attractions by perfecting local infrastructure and creating a series of characteristic tourist modes. In this case, can also drive the development of some local characteristics of products. It will extend the industrial chain of products, increase the added value of products, promote the development of local economy and promote the increase of people's income.

\section{Conclusion}

With the continuous development of Internet mode, ecommerce platform provides a good platform for people's shopping today, and has become a mainstream trend of people's consumption development. Nowadays, people pay more and more attention to the convenient mode of online shopping the current e-commerce model has been a development trend. Poor areas should pay more attention to the development of online e-commerce platform, actively integrate into the e-commerce development platform, to establish corresponding cooperation and exchange relations with e-commerce platform, and promote the development of some local agricultural products and characteristic industries. In addition to developing these, we should strengthen cooperation with relevant universities and scientific research institutes, continuously improve the quality of agricultural products, and enhance the professional knowledge and development skills of the local poor. In addition, we should actively explore a new model for the development of e-commerce poverty alleviation in the future. In short, the development of rural e-commerce has achieved some of the goals. On this basis, the development of rural e-commerce has a lot of innovation. In the future situation of e-commerce poverty alleviation, we should actively integrate with other latitudes of the development of agriculture, rural areas and farmers, and innovate a characteristic road of poverty alleviation on the basis of integration.

\section{References}

1. Wen,D.F.(2016)Re-war the Next Battlefield of Rural E-commerce "Internet" Age.Beijing: People's Post and Telecommunications Press.

2. Cui,L.L. Pan,S.L. (2016) Opportunities and Challenges of Rural E-commerce New Ecological Internet. Beijing: Electronic Industry Press.
3. Wang,H.L.(2018)Research on Main Problems and Countermeasures of Rural E-commerce in Poverty Alleviation.Economy.

4. Wu,X.Y.(2019)Analysis on the Path of E-commerce and Industry Poverty Alleviation in the Big Data Age. Electronic Commerce.

5. Chen,X.Q.Wang,Z.(2017)Discussion on the Implementation Path of Rural E-commerce Poverty Alleviation under the Background of Internet. Theoretical Guide.

6. Zhang,S.S.Feng,G.D.(2019)Research on the Innovation and Development of E-commerce in the Less Developed Areas of the West under the Background of Internet.Agriculture in Gansu.

7. Zhang,J.X.Xe,Y.L.(2018)A Study on the Poverty Alleviation Policy of E-commerce for Characteristic Agricultural Products under the Background of Internet - - Taking Gansu Province as an Example.Rural finance research. 